\title{
THE IMPACT OF REVIEWS ON THE INTERNET ON THE FINANCIAL RESULTS OF A HOTEL COMPANY
}

\author{
ANdRZEJ MATEUSZ WAJdA, ${ }^{1}$ SimONE PUORTO ${ }^{2}$ \\ 1 University of Rzeszów \\ Faculty of Sociology and History \\ Wajda Hotel Consulting \\ e-mail: andrzej@wajda.in \\ 2 ESSEC Business School \\ Simone Puorto Consulting \\ e-mail: info@simonepuorto.com
}

\begin{tabular}{l|l} 
JEL CODES & M31, Z30, Z33 \\
KEYWORDS & hotels, hospitality, reputation management
\end{tabular}

ABSTRACT This article reviews theoretically the impact of opinions about a hotel on the Internet on the financial results of a hotel company. The paper includes an overview of literature focused on hotel business and the reputation management concept which influence the decision-making process of guests. It presents other academic findings on this matter especially focusing on impact of reviews on hotel bookings and revenue. The aim of the article is to present previous research conducted in order to find if reviews on the Internet influence decisions of other people and at the same time influence hotel revenue. So far the academic field of explorations on this matter has been mostly unknown in Polish literature. The conclusions of this paper show online reviews which have generally a positive influence on consumers' decision to purchase hotel services. Most of the presented research indicate strong correlation between online consumer recommendations and financial results of hotels.

\section{Introduction}

As reviews are growing as an important factor of sharing experiences by guests, the hospitality industry has to consider them as equally important marketing factor. They play the role of continuous customer feedback which, as literature review shows, cannot be ignored by hotel management. The paper should be considered an introduction to hotel internet reviews and more broadly to the concept of reputation management. Both of them are new marketing communication channels and 
they are significant initiators of hotel financial performance. The subject of this paper is a still emerging topic in academic research and therefore there is limited literature about it and it is comparatively new. The authors reviewed the most important and current publications. The presented articles were evaluated as relevant and valid representation of the current knowledge about the discussed topic.

\section{Hotel Internet reviews}

Consumer Internet reviews constitute content produced and published by the so-called end users, whose subject is the evaluation of products and services, published on websites of the reviewed companies or of third parties (Ye, Li, Wang, Law, 2014).

English online Cambridge Dictionary defines the opinion (review) as a belief in something, a view of some matter; the way others rate others; specialist judgment on a subject; as well as someone's opinion about someone or something, judgment, opinion, view; reputation; assessment of someone or something expressed orally or in writing (Cambridge Dictionary, 2018).

Opinions have the form of comments in which people who used the services of a hotel, describe their experiences associated with them in the form of numerical and text evaluation. Text comments have the form of semantic descriptions of experiences. They refer to such areas of experience with a hotel as: infrastructure and amenities, location and access directions, rooms, beds, services, meals, communication, sales and booking process. In fact, everything guests can associate their own experience with while staying at a hotel.

Online hotel reviews belong to one of the categories of internet communication (computermediated-communication) as an electronic word-of-mouth (eWOM) (Tian, 2013). They also fit in the broader concept of reputation management of hotels.

The Internet enables easy and costless publication of content to individual users (user generated content). In this way, the consumer has the opportunity to influence what is being said about the hotel while co-creating its image in this way at the same time. The willingness of clients to evaluate hotels varies depending on the hotel standard as well as the hotel segment. Top-class hotels receive more opinions than properties from other segments (Miguens, Baggio, Costa, 2008). This implicitly confirms that opinions shape the image (or reflect it), and also become a part of it. Opinions are an immanent element of the image of a hotel, because negative entries can seriously tarnish its image (Hwang, Lai, Chang, Jiang, 2017). In studies not involving the hotel industry, S. Bambauer-Sachse and S. Mangold (2011) proved that bad opinions about products have a negative impact on the brand value, even if consumers know the brand.

Guest reviews are created and published for a variety of reasons. First and foremost, this is due to the universality and the features of the Internet. People use the Internet to share their own experiences from various events and experiences. In this way, assessing your stay in a hotel does not deviate in any way from other experiences. The incentives for publishing opinions may be as follows: willingness to interact socially, self-enhancement, helping the enterprise, caring for others, showing power. When writing a review, the guest may think that by assessing the service they help 
others decide on the choice of a hotel. Suggestions may be in the form of direct recommendation, as well as the description of the place itself. In this way, the potential guest is able to imagine the potential experiences and confront them with their own expectations. The need for social interaction is a motive resulting from the need for social belonging, because, as Youfei Tian writes: "travellers have the desire to write hotel reviews as a way to signify participation in and presence with the virtual community, which brings about the social benefit of integration and identification for the traveller." (Tian, 2013, p. 185). Self-enhancement in the sense of emphasizing one's own position and skills, refers to the expert position of an opinion-maker. By reviewing the object, the guest positions themselves as an expert, often underlining this role with the amount of opinions written as well as accentuating the amount of stays in a given place in the opinion. In this way, they appreciate themselves. and also the quality of own judgments, where the number of visits (or reviews) is to indicate the professionalism of writing and reliability of its entries.

\section{Hotel reputation management}

By publishing opinions, guests help the hotel company. Their opinions serve as a kind of market analysis because a review is a feedback message for a hotel carrying important information about the hotel and its services. Opinions build the image of hotels and market position (reputation). When properly analysed, they can serve as a full-fledged market research. Users directly and publicly express the assessment of the hotel and their needs. Feedback often includes an assessment of the level of satisfaction of needs. The guest not only judges the hotel itself, but also their own experiences and feelings about the needs that have been met or not and also, whether the communicated hotel image and the guest's expectations have been reflected in reality because the stay is their confrontation. Opinions, on the other hand, are its public articulation and the aspect of help may have an altruistic motive. When the guest tries to appreciate the hotel and the efforts of the staff, they reward their work not only with the payment resulting from the contract, but also through thanks and verbal valuation. Leaving a positive opinion also supports the hotel on a market level. Guests become a kind of ambassadors who, through recommendations, influence positive shopping decisions of subsequent guests. The help to a hotel company also has a second, less pleasant side as the customer can also exert power over the hotel. Negative ratings can simultaneously play a positive and negative role. In their opinion, the guest, pointing out shortcomings, is still trying to help the hotel, by paying attention to the elements that need improvement. However, the "power of opinion" also has a dark side. Consumers are aware that opinions affect others. So, leaving a negative opinion, they try to influence the hotel to achieve particular goals. In extreme cases, they are a bargaining element in blackmail with the hotel, which aims to gain own benefits (Tian, 2013). In order to prevent that, TripAdvisor created a "blackmail report tool" (TripAdvisor, 2018).

Opinions also provide authentic content, in contrast to the marketing messages of a hotel, which focus both on a real or exaggerated advantages the hotel communicates. However lately, there have been reports which cast real doubts on the review authenticity. The "mean of fake reviews is 32.9 percent whereas for B\&Bs, that figure rises to 41.9 percent" (Birchall, 2018). 
Therefore, opinions act as a verifier of officially provided information about a property both on the positive and negative level because they can also strengthen the official message, confirming the benefits contained in it and also to notice and emphasize its unreliability. They contain the actual experience of the consumer and their emotions associated with it. In addition, they are a source of recommendations and sensations after shopping which can be used at the same time by potential guests as well by hotel operators (Ye et al., 2014).

Opinions serve primarily to help other consumers. Thanks to them, the asymmetry of information on the market, between a hotel and a guest is reduced. The barrier of failure to inform the buyer in relation to a seller is thus significantly reduced. It thus aligns the chances of both players on the market. In this way, paradoxically, the seller (hotel) also gains, because greater knowledge favours better purchasing decisions and thus builds trust. Trust, in turn, is "a critical factor in stimulating purchases over the Internet" (Quelch, Klein, 1996).

Internet platforms that publish opinions act as intermediary agents between the seller and the buyer - the hotel and the guest. Currently, virtually every existing online portal containing reviews is primarily a place for the reservation of rooms. Opinions are a supporting element. In this way, these portals have become tourist agencies, with the only difference that they present in only on the Internet. A few years ago one could find platforms that were based only on opinions, without offering reservations. One of them, with a historical weight on the market, TripAdvisor, has evolved from the website publishing only reviews into the reservation platform. Although public opinion portals still exist, they do not focus only on the hotel industry. In this way, they are not a significant reference point for other consumers of commercial guest services, although hoteliers can still learn from them in the form of the abovementioned feedback from the market. The particular generalpurpose portals on which you can find hotel reviews and recommendations are social networking sites. Facebook and Google allow you to give an opinion directly to the hotel properties, that is, on the profile presenting the hotel and clearly associated with it. For other social networks such as Twitter, you can still leave a review about the hotel, but they are not aggregated in one form. This is closer to the phenomenon of eWOM and the traditional tools of this service, such as blogs and forums.

In summary, there are four main types of online platforms in which opinions are published. They are divided due to the following functions: review and planning - portals in which only the opinions of other users can be found (Lonely Planet, TripAdvisor - currently evolved into the metasearch platform and is going to be a social media platform for tourism); metasearch - search engines, aggregating information from many strictly booking portals, but having hotel rating options (Kayak, Trivago, currently TripAdvisor); public opinion platforms - all other websites where hotels can be directly or indirectly evaluated (social media, catalogues of offers); reservation platforms - intermediary pages for the sale of hotel services for a specific commission.

Booking platforms publish reviews for their own commercial purposes because they base their business model on commissions from sold rooms. In this way, the more rooms sold, the greater the profit of the platform. More opinions means more interest in a given hotel, more sales and, ultimately, higher revenue on the booking portal. Opinions help everyone in the triangle describing 
this business model: hotels, guests and the platforms themselves. As mentioned on the basis of the opinion, consumers build their knowledge and make decisions which leads to the sale and financial income of hotels and platforms. Booking portals also create demand through the advertising of their services and the presentation of hotel facilities on their websites, which in a way enhances the intent of purchasing by users. The negative phenomenon that may affect the booking platform are false opinions. They can be published by the hotels themselves to strengthen their position (positive) or reduce the position of competition (negative); but also by forewarned clients. Booking platforms ensure that they have procedures based on sophisticated algorithms and people, however, you can still encounter controversies related to unproven and untrue opinions.

When considering the effectiveness of an opinion, two aspects should be considered. Their valence and volume. Valence carries information about the sentiment of an opinion (positive or negative), a numerical rating and the ratio of positive ratings to negative ones. Volume tells us about the number of opinions published, but also about their length (Blal, Sturman, 2014).

The quality of opinions results from several features, which include sentence level informativeness, word level informativeness and product feature level informativeness. The first feature describes the number of sentences, their length and the number of sentences in which the features of the product-service are described. The second one informs about the number of words, the number of mentions about the product-service, as well as their name or brand. The third refers directly to the product-service described. The quality of opinion depends also on the author and their reputation in the given platform: how many reviews have been published so far and how they are evaluated in terms of usability (reliability) by other users. Many platforms have functionalities that also evaluate the writer's reputation. The qualitative evaluation features can also include transparency of the content, style of expression and its evaluation (Hwang et al., 2017).

The multiplicity of choice on the tourist market of hotels and the resulting information asymmetry requires solutions that help in choosing the right place to stay.

Thus, opinions play an important role - if not the most important - as an information medium about hotels in the Internet space because they provide up-to-date and reliable information for guests, or at least that is how they are seen. In this way, they influence the purchasing process of users.

According to Tuominen (2011) it can be broken down to the following steps:

a) selection from universally available options to a set of options that can be invoked consciously according to the variables needed;

b) narrowing down the selection from a set of deliberately available options to selected few, based on which the final choice will be made;

c) selection of one (several) options for the purchase transaction.

This process merges and permeates the hotel industry with the process of searching for information on the Internet. Based on this the booking decision is made. It consists of three elements:

a) a traveller whose decisions are initiated by internal needs or connected with the purpose or place of travel; 
b) online tourism domain, which consists of all participants of the tourist services market on the Internet, and is characterized by a separate semantic structure, defined by the hypertext nature of the Internet and the structure of the tourism industry;

c) search engines, where the search for places and the first contact with offer takes place.

The main system analysing the reputation of hotels, which was established long before the promotion of online reputation management, is a star standardization system. It has been popularized all over the world, even in countries where formal categorization requirements do not exist. Another solution that facilitates decision making is the existence of intermediaries in the form of travel agencies. Due to the close cooperation with hotels, knowledge of their services, but also the opinions of their customers, they have wider access to information. They serve as a recommendation place, thus eliminating the existing information asymmetry (Yacouel, Fleischer, 2012). The development of the Internet has enabled the development of intermediaries in the form of online travel agencies. They are available to individuals without special restrictions and in this way, information about services is freely available and it facilitates the decision-making process.

Published opinions are an element of the hotel's promotion, because as how Tian (2013, p. 185) summarizes: "text simultaneously promotes what it represents". Thus, they fit into the wider concept of the marketing mix because "hotel owners/managements still use their hotel reviews as a marketing strategy to ensure their competitiveness in the era of new capitalism" (Tian, 2013, p. 185).

\section{Financial impact of hotel reviews}

N. Yacouel and A. Fleischer proved that the quality of a service expressed in online reviews influences the price. So online reputation also affects the offline market because hotels improve the service to increase revenue. They also provide it to people who do not reserve on platforms where positive feedback has taken place. In addition, the larger hotel, the better (broader) reputation, which can allow the prices to rise. Chain hotels, which operate under the brand associated with a previously developed image, can charge prices higher by $4-14 \%$ from non-chain competition. It should be emphasized that price premium applies to international hotel chains. Among local ones, this relationship was not observed which would confirm the relevance of the image because by default, it can be assumed that international brands enjoy greater recognition and positive association. The research also showed significant relationships resulting from the traditional star system for reputation and price. In the examined hotels in Barcelona, London and Paris the following price differences were noticed: $30 \%$ - between a 1-star (1*) and two-star $\left(2^{*}\right)$ hotels; $70 \%$ - between $1^{*}$ and $3^{*}$; and $110 \%$ - between $1^{*}$ and $4^{*}$. In addition, the relationship between online reputation and the traditional positioning of a hotel's quality with stars has been proven. In the surveyed Booking. com portal, one point (on a ten-point scale) in the opinion of the guest, corresponds - depending on the destination - to one sixth to one-third of the traditional star. According to the authors, the implication of this may be treating the star system as a relic due to the fact that distribution on the Internet is becoming more and more common and the stars are no longer as important as they used 
to be. In addition, the star system standardizes the physical elements of the hotel and its infrastructure while not regulating the intangible qualities of a hotel enterprise which make up his offer and they are one of the main factors evaluated in booking platforms, e.g. the quality of the service or the value of the service (price-quality ratio). Abandoning the formal star system, as the authors think, will allow hotels to increase market efficiency thanks to a better allocation of available resources resulting from this change (Yacouel, Fleischer, 2012).

It is estimated that TripAdvisor itself is indirectly responsible for generating corporate travel sales of EUR 500 million in 2009. Moreover, TripAdvisor recognizes that $88 \%$ of all guests visiting booking portals (including those containing reviews) are influenced by the reviews they read during the hotel selection (Tuominen, 2011). In turn, in the World Travel Market report, we read that $35 \%$ of users change the decision of a selected hotel after reading the opinion on the Internet (Blal, Sturman, 2014). 74\% of tourists treat opinions as the main source of information when planning a trip. Viewing entries is one of the most popular activities that users take online (Ye, Law, $\mathrm{Gu}, 2009)$.

Tuominen (2011), in his research of TripAdvisor and hotel financial performance, proved the following:

a) there is a significant relationship between the number of published reviews and the average daily price (ADR) and the average price per available room (RevPAR) (Anderson, 2012);

b) the number of opinions may also influence the hotel occupation rate, however, here the correlation is not so significant, and it differs between the places studied;

c) the average review grade is positively correlated with the average price and average price for an available room;

d) a high correlation also exists between the average of review rates and the occupancy of a hotel;

e) the percentage recommendation rate of users has a high impact on the hotel turnout, and its relationship was the strongest of all the factors studied;

f) the percentage recommendation rate of users also affects the average price for an available room, and the average price of the day, although in this case the relationship is not strong;

g) no dependence between the hotel results and the ranking of hotels on TripAdvisor.

C. Anderson's (2012) research, which analysed, among other things: the position of the hotel in the Internet search engine, the rating on the Travelocity.com portal, the number of reservations and the relative price, showed that the value and quantity of reviews on the website increases the probability of sale in the website itself, as well as in other Internet channels, but also in traditional ones. In fact, online assessments affect the global outcome of the hotel, not just on the Internet.

I. Blal and M. Sturman (2014), analysing the influence of value and quantity of opinions, proved that numerical ratings have a greater impact on the results of higher-class hotels, while the number of opinions is more important for a lower-standard properties. It is important that the study has demonstrated the same impact on hotels, regardless of the category they belong to. Dependency exists for both independent, franchise and chain hotels. The authors suggest that for hotels with a high standard, it is advisable to have fewer opinions, but with a high numerical value, 
which justifies the claim that a smaller number of good quality reviews confirms the luxurious positioning of the hotel, its limited availability for certain segments of guests, and thus exclusivity. A considerable number of opinions may contradict this image, thus discouraging high-status people from using this type of hotel which can cause worse financial results of the property. The lower the hotel standard, the smaller the impact on the hotel results. Analysing the standard of the hotel, the number of opinions affects the hotel results, in that the lower the standard, the more the number of opinions affects its popularity and financial effects. In summary, the analysis distinguishes hotel segments to assess the actual impact of the opinions (and their value and quantity), as both quantity and quality are important, but the scope and even the nature of the impact depends also on the characteristics of the hotel product itself. Another feedback that the reviews bring is the perception of prices by the guests after the stay has ended. The price affects how the guests later assess the quality and value of the service. Typically, the price has a positive impact on the quality of services, but a negative one when it comes to their value. There is also a dependence where, due to the price, quality is more important in hotels with a higher standard. The perceived value, in turn, is more important for guests of the business segment than for tourists concentrating on leisure.

Vermeulen and Seegers (2009) proved that positive opinions improve the hotel image among consumers. In the same study, they found that positive and negative opinions build awareness about the existence of the hotel brand, although a negative one may affect the hotel's result. However, the developed consciousness can neutralize unwanted effects. Value of the opinion helps in the sale of rooms in the Internet channels (Ye, Law, Gu, Chen, 2011).

It is worth noting that there are studies which do not confirm the influence of online reputation on the sales of a hotel. However, still there is a correlation that allows for prediction of sales based on published ratings, but this is not a cause-effect relationship.

In the research conducted by A. Mauria and R. Minazzib (2013), 75\% of respondents answered that they consider the opinions of others before making a decision on hotel reservation. In the same study, it was proved that the value of ratings, even on non-booking platforms, positively correlates with the intent of concluding a reservation somewhere else. Opinions therefore have a wide range, beyond the place of publication. In addition, the value of assessments affects the expectations of future consumers. Better opinions create higher expectations. Interestingly, it turned out that the ability to respond to guest feedback, which currently exists in most portals, may negatively affect buying intentions. The authors justify this claiming that such a hotel response can be perceived as an advertisement, and thus it is unreliable. And also, as a result of mercantile motives, it does not attempt to satisfy the guest's doubts. Opposite findings were presented by Dai and Jiang (2016) where the management response to online reviews has a significant adjustment effect in consumer decision-making process.

\section{Conclusions}

Reputation in the case of hotels primarily affects the consumer's decision to select accommodation. We can observe this process in two forms: a guest choosing different destinations can choose 
one brand of a hotel, or they recommend a brand (hotel) in which they have already stayed to other consumers. It has been proven that the positive image of the company in terms of the quality of its services neutralizes negative reviews related to the asymmetry of market information. At the same time, it affects the profitability and overall success of the company. Reputation is closely related to consumer confidence. Customers' trust in turn, for example in the quality of services, allows for a higher valuation of services since guests are willing to pay more for the services they trust. In this way, offering services at a high level has economic justification, however, for this purpose it is necessary for reliable information about the quality of services to reach future consumers.

\section{References}

Anderson, C. (2012). The impact of social media on lodging performance. Cornell Hospitality Report, 12 (15), 6-11.

Bambauer-Sachse, S., Mangold S. (2011). Brand equity dilution through negative online word-of-mouth communication. Journal of Retailing and Consumer Services, 1 (18), 38-45.

Blal, I., Sturman, M.C. (2014). The differential effects of the quality and quantity of online reviews on hotel room sales. Cornell Hospitality Quarterly, 4 (55), 365-375.

Birchall, K. (2018). Five star "fakary" "One in three TripAdvisor reviews are FAKE" with hotels and restaurants buying glowing reviews for $£ 7$, investigation finds. The Sun. Retrieved from: https://www.thesun.co.uk/news/7321574/ tripadvisor-reviews-fake-hotel-restaurant-ratings.

Cambridge dictionary (2018). Opinion; Review. Retrieved from: https://dictionary.cambridge.org/dictionary/english.

Chiang, C., Jang, S. (2007). The Effects of Perceived Price and Brand Image on Value and Purchase Intention: Leisure Travelers' Attitudes Toward Online Hotel Booking. Journal of Hospitality \& Leisure Marketing, 3 (15), 49-69.

Dai, Y., Jiang, Y. (2016). The Research of Online Reviews' Influence towards management response on Consumer Purchasing Decisions. Presented at WHICEB 2016 Proceedings, 43.

Hwang, S., Lai, C., Chang, S., Jiang, J. (2014). The Identification of Noteworthy Hotel Reviews for Hotel Management. Pacific Asia Journal of the Association for Information Systems, 4 (6), 1-17.

Kandampully, J., Hu, H. (2007). Do hoteliers need to manage image to retain loyal customers? International Journal of Contemporary Hospitality Management, 6 (19), 435-443.

Kim, H., Kim, W., An, J.A. (2003). The effect of consumer-based brand equity on firms' financial performance. Journal of Consumer Marketing, 4 (20), 335-351.

Mauria, A., Minazzib, R. (2013). Web reviews influence on expectations and purchasing intentions of hotel potential customers. International Journal of Hospitality Management, 34, 99-107.

Miguens, J., Baggio, R., Costa, C. (2008). Social media and tourism destinations: TripAdvisor case study. Presented at IASK Advances in Tourism Research, Aveiro, Portugal, 194-199.

Quelch, J.A., Klein, L.R. (1996). The Internet and international marketing. Sloan Management Review, 3 (37), 60-75.

Tian, Y. (2013). Engagement in online hotel reviews: A comparative study. Discourse, Context and Media, 2 (4), $184-191$.

TripAdvisor. (2018). Reporting Potential Blackmail to TripAdvisor: Report Threats Immediately. Retrieved from: https:// www.tripadvisor.com/TripAdvisorInsights/w592.

Tuominen, P. (2011). The Influence of TripAdvisor Consumer-Generated Travel Reviews on Hotel Performance. University of Hertfordshire Business School Working Paper.

Vermeulen, I., Seegers, D. (2009). Tried and tested: the impact of online hotel reviews on consumer consideration. Tourism Management, 1 (30), 123-127.

Yacouel, N., Fleischer, A. (2012). The role of cybermediaries in reputation building and price premiums in the online hotel market. Journal of Travel Research, 2 (51), 219-226.

Ye, Q., Law, R., Gu, B. (2009). The impact of online user reviews on hotel room sales. International Journal of Hospitality Management, 1 (28), 180-182. 
Ye, Q., Law, R., Gu, B., Chen, W. (2011). The influence of user-generated content on traveler behavior: an empirical investigation on the effects of e-word-of-mouth to hotel online bookings. Computers in Human Behavior, 2 (27), 634-639.

Ye, Q., Li, H., Wang, Z., Law, R. (2014). The Influence of Hotel Price on Perceived Service Quality and Value in E-Tourism: An Empirical Investigation Based on Online Traveler Reviews. Journal of Hospitality \& Tourism Research, 1 (38), 23-39.

\section{WPEYW OPINII W INTERNECIE NA WYNIKI FINANSOWE FIRMY \\ HOTELARSKIEJ}

\section{SŁOWA KLUCZOWE \\ STRESZCZENIE}

hotele, hotelarstwo, zarządzanie reputacją

Artykuł teoretycznie analizuje wpływ opinii hotelu w Internecie na wyniki finansowe firmy hotelarskiej. Artykuł zawiera przegląd literatury koncentrującej się na biznesie hotelowym i koncepcji zarządzania reputacją, które wpływają na decyzje podejmowane przez gości. Przedstawiono dotychczasowe wyniki badań akademickich w tej dziedzinie, ze szczególnym uwzględnieniem wpływu opinii w Internecie na rezerwacje usług hotelowych, a tym samym przychody finansowe hoteli. Celem artykułu jest przegląd i podsumowanie dotychczasowych badań, ponieważ obecnie akademickie pole eksploracji w tej dziedzinie jest $\mathrm{w}$ większości nieznane $\mathrm{w}$ literaturze polskiej. Wnioski z tego artykułu wskazują, iż opinie online mają ogólnie pozytywny wpływ na decyzje konsumentów dotyczące zakupu usług hotelowych. Wskazać także można korelację między rekomendacjami internetowymi konsumentów a wynikami finansowymi hoteli. 